\title{
Kegiatan Meremas Koran Dalam Mengembangkan Kemampuan Motorik Halus Anak Usia Dini
}

\author{
Agustina Budiarti $^{1}$, Anik Lestariningrum ${ }^{2}$, Isfauzi Hadi Nugroho ${ }^{3}$ \\ ${ }^{1,2,3}$ Universitas Nusantara PGRI Kediri \\ Kediri, Indonesia \\ Email: agustiaamstia20@gmail.com ${ }^{1}$, aniklestariningrum@gmail.com², isfauzi@unpkediri.ac.id ${ }^{3}$
}

Kata kunci:

koran, motorik

halus, anak usia dini

\begin{abstract}
Abstrak
Permasalahan yang terjadi dalam pengembangan kemampuan pada anak usia dini terkait kemampuan motorik halus anak terkait koordinasi jari tangan dalam kaitannyan dengan kelenturan jari tangan menyebabkan anak mengalami kesulitan dalam menggengam alat tulis dan alat makan. Untuk membantu permasalahan tersebut kegiatan bermain meremas koran menjadi alternatif solusi pembelajarannya. Pemanfaatkan koran bekas sebagai alternatif akan menstimulasi perkembangan motorik halus. Tujuan dari penelitian untuk memaparkan kegiatan bermain meremas koran untuk mengembangkan kemampuan motorik halus pada anak. Desain penelitian deskriptif kualitatif dengan teknik penilaian observasi, dan dokumentasi. Adapun instrumen penelitian yang digunakan adalah pedoman observasi dan wawancara yang dianalisis secara deskriptif menggunakan analisis model Miles dan Huberman. Subjek penelitian ini adalah anak kelompok bermain ceria Desa Kudu Kecamatan Kertosono Kabupaten Nganjuk yang berjumlah 10 siswa. Hasil penelitian diperoleh data sebanyak 8 anak mendapat predikat berkembang sangat baik dan 2 anak mendapat predikat mulai berkembang. Kesimpulan dalam penlitian ini kegiatan meremas koran dapat mengembangkan kemampuan motorik halus anak usia dini.
\end{abstract}

Keywords:

News papers, fine motor skills, early childhood

\begin{abstract}
Problems that occur in developing abilities in early childhood are related to children's fine motor skills related to finger coordination in relation to finger flexibility which causes children to experience difficulty in holding stationery and eating utensils. To help with this problem, playing squeezing newspapers is an alternative learning solution. Using old newspapers as an alternative will stimulate fine motor development. The purpose of this research is to describe the activity of playing squeezing newspapers to develop fine motor skills in children. Descriptive qualitative research design with assessment techniques, observation and documentation. The research instrument used was the observation and interview guidelines which were analyzed descriptively by the analysis of the Miles and Hubermen model. The subjects of this study were 10 children of the Cheerful Play Group in Kudu Village, Kertosono District, Nganjuk Regency. The results showed that 8 children received the predicate of developing very well, and 2 children received the title of starting to develop. The conclusion in this study is the activity of squeezing newspapers can develop the motor skills of early childhood.
\end{abstract}




\section{Pendahuluan}

Unik, istimewa dan berbeda, kalimat tersebut adalah kalimat yang sering digunakan untuk menggambarkan atau mendeskripsikan anak usia dini. Namun kalimat tersebut tidaklah cukup untuk menggambarkan atau mendeskripsikan anak usia dini yang pada setiap tahap perkembangannya memiliki pencapaian yang sangat beragam. Anak usia 0-6 tahun adalah anak yang usia perkembangan seluruh aspeknya sangat cepat, itulah mengapa pada usia 0-6 tahun disebut dengan usia keemasan atau golden age, yang mana perlu stimulasi fokus dan tepat yang bisa digunakan. Hal ini seperti pendapat Lestariningrum (2019) terkait konsep anak usia dini, yang mana anak akan memiliki aspek yang harus dikembangkan salah satu fokusnya adalah bagaimana keterampilan motorik diharapkan dapat dikuasai secara optimal oleh anak sejak dini. Hal ini dikemukakan Hurlock (1978), yang mana aspek perkembangan motorik adalah bagaimana individu dapat mengendalikan beragam gerakan dalam aktivitas jasmani melalui koordinasi pada pusat syarafnya, berkaitan dengan urat syaraf dan ototnya. Di mana pengembangan aspek ini dapat dilakukan dengan beragam kegiatan menarik dan menyenanagkan sesuai tahapan usia.

Salah satu penelitian pengembangan terkait motorik yang dilakukan oleh Claudia dkk (2018) menhasilkan bahwa kegiatan menyenangkan yang dipilih dalam peningkatan motorik halus adalah permainan origami. Kegiatan origami melibatkan koordinasi jari tangan dan otot tangan, sehingga dapat memotivasi minat anak menggerakan otot-otot kecilnya. Penelitian ini juga menekankan kegiatan yang dipilih pada anak usia 4-5 tahun di mana menyiapkan anak keterampilan menulis dan menggambar dikombinasi dengan membuat lipatan beragam bentuk dari permainan origami. Saat anak membuat lipatan bebentuk lurus, miring ataupun juga lengkung, di situ memerlukan koordinasi syaraf yang berkaitan otot halusnya.

Penelitian sejenis terkait menghasilkan sebuah karya dilakukan juga oleh Yunia dkk (2017) terkait kegiatan yang dilakukan yaitu membentuk dengan media spons. Pemilihan kegiatan ini berdasarkan pengamatan saat kegiatan berlangusng anak banyak menggunakan gerak tangan dalam memegang spon melatih koordinasi jari-jemari, gerakan tangan ke siku bahkan adanya koordinasi antara indera mata beserta kegiatan aktifitas gerakan tangan. Tujuan yang dapat terliihat dari membentuk dengan media spon ini adalah melatih kemampuan motorik halus yang ada kaitannya dengan menggerakan anggota tubuh khususnya kedua tangan yang mana kegiatan ini membutuhkan latihan secara terus menerus agar keseimbangan optimal dapat tercapai.

Penelitian tentang bermain meremas bubur kertas di TK sudah pernah dilakukan oleh Najamuddin (2017), peningkatan motorik halus anak dilakukan mulai dengan kegiatan meremas, mencetak dan bagaimana menggunakan alat cetak dari bubur kertas yang dihasilkan ternyata bermanfaat dalam stimulasi keterampilan anak dalam hal mengkoordinasi otot-otot kecilnya sebagai proses awal berkembangnya motorik anak tersebut. Pemilihan bahan ini berdasarkan banyak ditemukan di sekitar lingkungan dan sebagai upaya pemanfaatan dari bahan bekas.

Terkait pemilihan kegiatan meremas juga sudah pernah dilakukan oleh Fulanatin dan Simatupang, (2016) pada anak usia 3-4 tahun, yang mana hasil yang diperoleh saat capaian perkembangan motorik halus anak mengacu pada konsep yang dikemukakan oleh Santrock (2002) yang mana gerakan meremas, menggenggam mainan, mengancingkan baju ataupun kegatan lain yang melibatkan keterampilan tangan melibatkan gerakan secara halus tertata merupakan capaian yang akan dilakaukan dalam pengembangan khususnya motorik halus. Anak usia 3-4 tahun memang memerlukan stimulasi yang lebih sederhana kegiatannya dibandingkan 
dengan anak usia lebih dari 4 tahun, karena selain fokus kegiatan, anak belum dapat bertahan lama. Anak masih mencari teknik melenturkan koordinasi jemarinya supaya dapat berfungsi dengan baik. Intinya, dengan kegiatan bermain yang penuh rasa senang dan gembira, anak usia dini belajar pengembangan apapun dengan bermain. Motorik halus juga dirancang dengan bermain sebagai aktiitas yang dilakukan.

Bermain sendiri menurut Andini dan Lestariningrum (2018) merupakan fantasia atau lamunan, sehingga anak dapat memproyeksikan harapan-harapan maupun konflik pribadi. Selain dapat meningkatkan perkembangan motorik halus pada anak, kegiatan bermain meremas koran juga mempunyai nilai positif yaitu untuk memanfaatkan koran bekas yang ada di lingkungan sekitar supaya lebih bermanfaat dan tidak begitu saja terbuang. Dengan kegiatan bermain meremas koran diharapkan dapat memberi stimulasi agar jari jemari anak lebih lentur dan kemampuan motorik halusnya dapat berkembang dengan maksimal.

Berkaitan dengan kajian penelitian pengembangan motorik halus yang sudah dikemukakan di atas, dari hasil observasi yang dilakukan di KB Ceria Desa Kudu Kecamatan Kertosono Kabupaten Nganjuk, terdapat berbagai permasalahan yang ditemukan, salah satu permasalahan yang dirasa paling tepat untuk diteliti dalam penelitian ini adalah belum berkembangnya kemampuan motorik halus pada anak berupa koordinasi jari tangan yang membuat jari jemari anak belum mampu untuk memegang alat tulis, seperti pensil, krayon dan gunting dengan kuat. Jari jemari anak memegang alat tulis menggunakan ujung jari telunjuk dan jari jempol, hal tersebut membuat anak terlihat ragu-ragu dalam menggoreskan tulisan menggunakan alat tulis. Akibatnya terlihat anak saat belajar bermain warna dengan pensil dan crayon belum berkembang optimal serta saat anak makan sendiri memegang alat makan terkait memegang sendok banyak yang belum dapat memasukan nasi dengan baik ke mulutnya, karena koordinasi jari-jemarinya kurang berkembang secara baik.

Pemberian stimulus yang tepat sangat dibutuhkan dalam mengembangkan motorik halus anak, salah satunya dengan kegiatan yang bervariatif dan menyenangkan yang nantinya membuat anak tertarik dan tidak merasa bosan dengan pembelajaran yang terpaku pada lembar kerja. Seperti halnya yang dikemukakan oleh Hurlock (1978) salah satunya adalah melalui keterampilan motorik halus anak dapat menghibur dirinya dan memperoleh rasa senang. Dari beragam pendapat dan permasalahan tersebut ditekankan betapa pengembangan aspek motorik halus menjadi penting dilakukan dengan kegiatan sederhana dan menarik sesuai kondisi yang ada di masing-masing lembaga. Karena ketidaktercapaian keterampilan menggkoordinasi kegiatan dengan jari-jemari, tangan, dan koordinasi mata dapat menyebabkan perkembangan lain terganggu.

Pemilihan kegiatan meremas juga dilakukan berdasarkan penelitian yang dilakukan oleh Sartika (2013) yang mana kegiatan terkhusus pada meremas adonan yang dilakukan pada anak tunagrahita ringan. Penelitian tersebut menghasilkan sebuah rujukan kesulitan yang dialami anak saat menulis permulaan dapat distimulasi dengan menggerakan jari-jari tangannya. Kerja motorik ini meningkat dengan melakukan kegiatan meremas adonan. Adonan yang digunakan berupa bahan pembuatan kue donat. Sementara pada penelitian yang dilakukan di KB Ceria menggunakan meremas koran bekas menjadi adonan bubur koran.

Landasan inilah yang membuat peneliti tertarik dalam memilih kegiatan meremas dengan kertas koran yang akan diterapkan pada anak didik usia 3-4 tahun. Alasan kuat adalah kegiatan ini selain mudah dilakukan anak, menarik dengan anak megalami sendiri supaya ketika kegiatan berlangsung, otot halus pada telapak tangan dan gerakan jarinya semakin matang dan juga dapat menciptakan beragam imajinasi dari hasil karyanya dengan meremas koran tersebut.

Child Education Journal. Volume 2, No. 2 December 2020, 106-113 


\section{Metodologi}

Metode yang digunakan dalam penelitian ini ialah metode kualitatif di mana peneliti menggambarkan hasil secara narasi terkai temuan langung kejadian yang dialami selama melakukan pengumpulan data. Teknik pengumpulan data yang digunakan menerapkan pedoman observasi atau pengamatan dan pedoman wawancara.

Subjek dalam penelitian ini adalah anak usia 3-4 tahun Kelas Bermain Ceria Desa Kudu Kecamatan Kertosono Kabupaten Nganjuk sebanyak 8 anak didik. Indikator keberhasilan dari penelitian ini adalah meningkatnya kemampuan motorik halus anak dengan ditunjukan pengolahan data secara deskriptif kualitatif berdasarkan deskriptif analisis model Miles dan Huberman yaitu tahap reduksi data, tahap penyajian data/analisis data setelah pengumpulan data dan tahap penarikan kesimpulan dan verifikasi.

\section{Hasil Dan Pembahasan}

Berdasarkan pada hasil observasi/pengamatan yang telah dilakukan di KB Ceria Desa Kudu Kecamatan Kertosono Kabupaten Nganjuk, yaitu kegiatan bermain meremas koran yang bertujuan untuk mengembangkan kemampuan motorik halus pada anak usia dini diperoleh capaian hasil perkembangan seperti dibawah ini:

Tabel 1. Hasil Observasi Capaian Perkembangan Motorik Halus Anak KB Ceria dengan Kegiatan Meremas Koran

\begin{tabular}{|c|c|c|c|c|c|}
\hline \multirow{2}{*}{ No } & \multirow{2}{*}{ Indikator } & \multicolumn{4}{|c|}{ Hasil Perkembangan } \\
\hline & & BB & MB & BSH & BSB \\
\hline 1 & Anak mampu memasukkan koran kedalam air & & 1 & 9 & \\
\hline 2 & Anak mampu meremas koran yang ada di dalam air & & 3 & & 7 \\
\hline 3 & $\begin{array}{l}\text { Anak mampu melakukan kegiatan meremas Koran dan } \\
\text { menghancurkannya menjadi bubur koran dengan jarinya }\end{array}$ & & & 8 & 2 \\
\hline 4 & $\begin{array}{l}\text { Anak mampu membentuk bubur koran hasil remasan menjadi } \\
\text { benda sesuai tema ataupun bentuk yang disukai }\end{array}$ & & 3 & 7 & \\
\hline 5 & Anak mampu mengkomunikasikan hasil karyanya & & 4 & & 6 \\
\hline
\end{tabular}

Berdasarkan hasil di tabel 1 di atas menunjukan dari indikator pengamatan perkembangan motorik halus anak dengan kegiatan meremas Koran sudah tidak ada yang BB (Belum Berkembang), tetapi sudah pada tahapan minimal minat anak muncul untuk melakukan kegiatan bahkan ada yang sudah BSH (Berkembang Sesuai Harapan). Berikut hasil yang diperoleh sebelum dilakukan kegiatan meremas koran seperti ditampilkan pada tabel berikut ini:

Tabel 2. Hasil Observasi Capaian Perkembangan Motorik Halus Anak KB Ceria Sebelum Kegiatan Meremas Koran

\begin{tabular}{|c|c|c|c|c|c|}
\hline \multirow{2}{*}{ No } & \multirow{2}{*}{ Indikator } & \multicolumn{4}{|c|}{ Hasil Perkembangan } \\
\hline & & BB & MB & BSH & BSB \\
\hline $\mathbf{1}$ & Anak mampu memasukan koran kedalam air & 5 & 4 & 1 & \\
\hline 2 & Anak mampu meremas koran yang ada didalam air & 3 & 7 & & \\
\hline 3 & $\begin{array}{l}\text { Anak mampu melakukan kegiatan meremas Koran dan } \\
\text { menghancurkan menjadi bubur Koran dengan jarinya }\end{array}$ & 4 & 4 & 2 & \\
\hline 4 & $\begin{array}{l}\text { Anak mampu membentuk bubur Koran hasil remasan menjadi } \\
\text { benda sesuai tema ataupun bentuk yang disukai }\end{array}$ & 3 & 7 & & \\
\hline 5 & Anak mampu mengkomunikasikan hasil karyanya & 4 & & 6 & \\
\hline
\end{tabular}

Child Education Journal. Volume 2, No. 2 December 2020, 106-113 
Berdasarkan hasil di tabel 2 di atas menunjukan capaian indikator perkembangan motorik halus anak KB Ceria sebelum diberikan kegiatan meremas koran menujukan bahwa terdapat anak yang masih di BB (Belum Berkembang) lebih banyak dibandingkan pada yang MB bahkan capaian tertinggi di BSB (Berkembang Sangat Baik) itupun hanya tertinggi di kemampuan mengkomunikasikan belum pada keterampilan koordinasi tangan dan jari untuk perkembangan motorik halus. Apabila dibandingkan hasilnya dapat dilihat pada grafik dibawah ini:
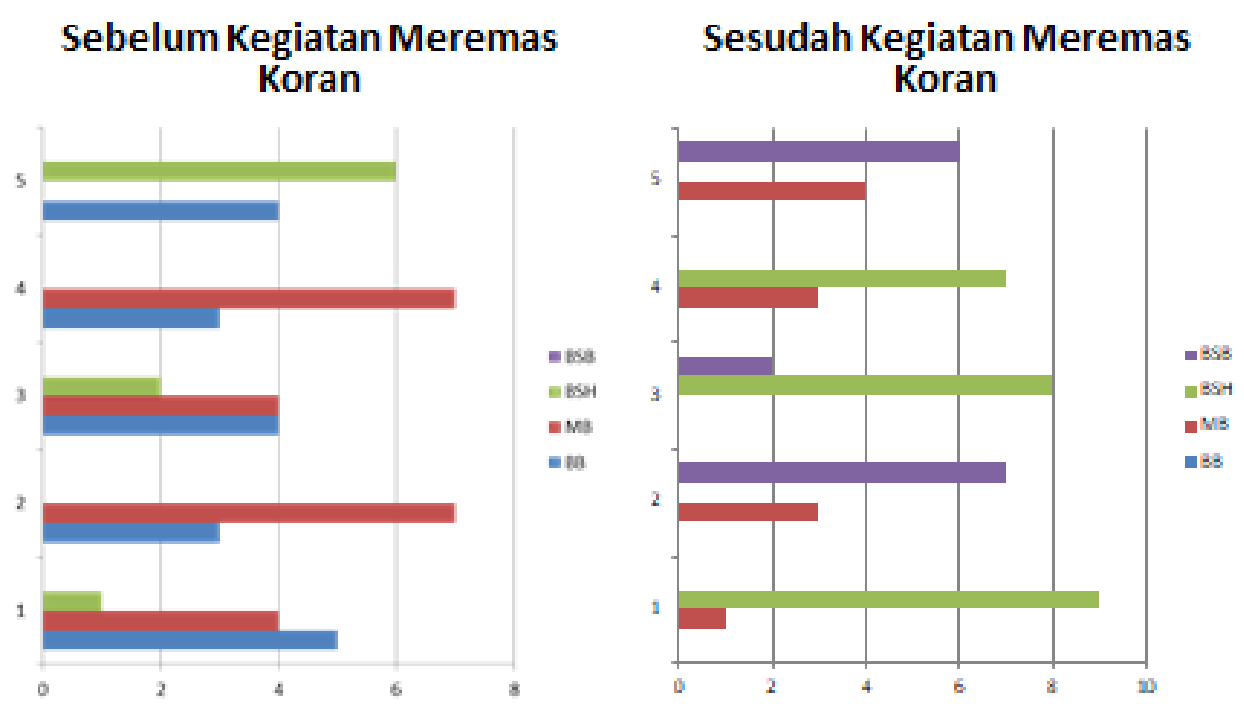

Gambar 1. Diagram Perbandingan Sebelum dan Sesudah Kegiatan Meremas Koran

Pada diagram di atas menunjukan bahwa warna biru untuk capaian Belum Berkembang (BB) didominasi capaian perkembangan motorik halus ada pada sebelum diberikan kegiatan meremas Koran, sedangkan setelah kegiatan hasil perkembangan grafik warna hijau dengan capaian BSH (Berkembang Sesuai Harapan). Dengan melihat perbandingan ini, jelas terlihat hasil capaian perkembangan motorik halus dengan kegiatan meremas koran.

Berdasarkan analisis melalui wawancara dan juga pengiriman dokumentasi oleh orang tua, masih ada capaian anak yang mulai berkembang ditekankan anak memiliki ketakutan untuk mencoba melakukan kegiatan baru cenderung jijik ketika harus melakukan kegiatan bermain meremas koran yang telah dimasukan ke dalam air. Faktor kendala pencapaian ini kemudian dikaitkan saat anak di sekolah sehari-hari memang memiliki kecenderungan harus didampingi dan diberikan motivasi lebih, kemudian kebebasan bermain dengan air atau bahan kotor kurang diberikan di rumah oleh orang tuanya.

Minat yang dimiliki anak akan semakin berkembang apabila anak diberikan kesempatan untuk terlibat langsung dalam kegiatan, meskipun dengan pengawasan guru atau orang tua disekitarnya. Apalagi kegiatan koordinasi tangan dan jari pada meremas koran ini sebenarnya kegiatan sederhana yang bisa dilakukan di rumah bersama orang tua, tetapi manfaat yang diperoleh pada stimulasi kemampuan motorik halus sangat besar terutama menyangkut keberanian anak dalam mencoba melakukan percobaan dengan penggalian pengalaman secara langsung.

Berikut adalah dokumentasi yang diperoleh oleh peneliti dari hasil pengamatan dan hasil karya proses meremas koran bekas menjadi bentuk benda: 
Tabel 3. Hasil Dokumentasi Proses Bermain Meremas Kertas Koran

\begin{tabular}{|c|c|}
\hline Hasil Dokumentasi & Analisis \\
\hline & $\begin{array}{l}\text { - Anak didampingi oleh orang tuanya menyiapkan alat bahan dan } \\
\text { melakukan kegiatan meremas Koran bekas yang dimasukan ke dalam } \\
\text { air dalam ember } \\
\text { - Sebelumnya, guru berkomunikasi dengan orang tua melalui media } \\
\text { WAG wali murid supaya orang tua memahami saat proses kegiatan } \\
\text { main dan tujuan pembelajaran untuk anak }\end{array}$ \\
\hline & $\begin{array}{l}\text { - Hasil dari salah satu kiriman orang tua tentang karya anak di mana } \\
\text { capaian masih mulai berkembang } \\
\text { Nampak hasil remasan kurang padat kurang berbentuk karena } \\
\text { koordinasi jari jemari anak kurang menekan keras dan juga terlihat } \\
\text { dilakukan dengan ragu, karena ada ketakutan atau jijik meremas koran } \\
\text { dengan air seperti yang diceritakan orang tua saat diwawancarai oleh } \\
\text { guru }\end{array}$ \\
\hline & $\begin{array}{l}\text { - Hasil dari salah satu kiriman orang tua tentang karya anak di mana } \\
\text { capaian berkembang sesuai harapan } \\
\text { - Hasil remasan padat dan berbentuk bola yang tidak ada kandungan air } \\
\text { di dalam hasilnya karena kuatnya anak menekan dengan jemarinya } \\
\text { - Kekuatan dalam meremas merupakan koordinasi syaraf otot halus } \\
\text { pada telapak jari, jari tangan dan kekuatan tangan, sehingga } \\
\text { menghasilkan stimulasi aspek motorik halus yang dicapai anak lebih } \\
\text { optimal untuk menyiapkan tahapan perkembangan selanjutnya }\end{array}$ \\
\hline
\end{tabular}

Berdasarkan paparan hasil penelitian yang dikemukakan di atas didukung oleh dokumentasi kegiatan bermain tampak anak-anak sangat antusias dalam melakukan kegiatan bermain meremas koran, hal ini dikarenakan media koran dan air yang digabung dapat memicu minat anak bereksplorasi menemukan sendiri pengetahuannya sesuai struktur kognitifnya. Hal ini didukung oleh Hurlock (1978) yang menjelaskan bahwa salah satu fungsi pengembangan aspek motorik halus pada anak adalah membuat anak dapat terhibur, karena ada efek rasa senang dan menggembirakan serta adanya penyesuaian terhadap lingkungan sekitar, apabila menemukan koran bekas dapat digunakan dalam kegiatan belajar bermakna bagi anak. Pada saat kegiatan bermain meremas koran inilah, anak mengontrol koordinasi gerakan telapan tangan dan jarinya, sehingga gerakan jemarinya semakin lincah. Hal ini didukung oleh Beaty (2013) yang menjelaskan bahwa terkait kegiatan yang dilakukan apabila melibatkan otot-otot halus terutama dalam pengendalian khususnya koordinasi, ketangkasan melakukan kelincahan gerak menggunakan jemari dan tangannya akan sangat berpengaruh pada kemampuan motorik halus anak.

Keterampilan motorik halus dianggap gerakan kecil otot yang melibatkan penggunaan tangan dan jari secara bersama untuk melakaukan gerakan. Jenis-jenis gerakan saat meremas akan membentuk koordinasi kemudian anak dapat menyelesaikan tugas berkaitan dengan dirinya mengancingkan kemeja, mengikat tali sepatu, memegang pensil, menggunakan peralatan, mengetik pada keyboard, hal ini disebabkan kuatnya sensori setelah distimulasi dengan beragam kegiatan. Seperti tulisan di Michigan state University yang dikemukaan oleh Moyses (2016), menyarankan kegiatan dalam mengembangkan motorik halus salah satunya bermain adonan, dan meremas dengan mempraktikan keterampilan motorik halus tersebut akan 
membantu anak-anak memiliki landasan lebih lanjut untuk tugas-tugas sehari-hari mereka di masa depan.

Membuat adonan bubur saat meremas koran menurut Sartika (2013) yang menjelaskan bahwa saat gerakan mengadon terdapat proses menyatukan dan mengaktifkan adanya kekuatan mental membentuk sesuatu gerakan memutar, meremas, memadatkan/menyatukan dan juga menyatukan jaringan mental neuron, gerakan jemari tangan akan menjadi pandangan hasil penting karena akan menjadi perwujudan dan mengungkapkan proses pembelajaran terhadap makna pemahaman dirinya. Meremas adonan atau bubur koran yang mana koran dimasukan air saat kegiatan merupakan rangkaian kegiatan yang berurutan langkahnya, sehingga akan terus menggerakan jari-jari dalam meremas koran dengan tepat menstimulasi perkembangan motorik halus anak.

Pembahasan terkait kemampuan motorik halus di KB Ceria setelah diberikan kegiatan bermain meremas koran dapat meningkat. Aktivitas gerakan menekan dan meremas air dari bubur koran membentuk benda tertentu sesuai tema atau minat anak memerlukan keseimbangan syaraf jari dan tangan. Hurlock (1978) menjelaskan bahwa ketika sebuah koordinasi terkaiit urat syaraf anak apabila dimulai sejak dini dan sering dilakukan serta dilatih akan diperoleh sebuah kematangan dalam diri anak, sehingga keterampilan motorik pada diri anak akan tercapai dengan baik. Hal ini didukung oleh penelitian yang dilakukan oleh Widayati dkk (2019) yang menunjukkan hasil bahwa tahapan menggunting dapat meningkatkan kemampuan motorik halus anak pada siklus I sebesar $81,8 \%$ meningkat menjadi $86,4 \%$ pada siklus II.

\section{Kesimpulan}

Berdasarkan hasil dan pembahasan pada penelitian ini dapat disimpulkan bahwa adanya capaian perkembangan motorik halus anak meningkat dengan melakukan kegiatan bermain meremas kertas koran. Keefektifan kegiatan bermain ini sesuai dengan tahapan perkembangan anak, sehingga disaraankan bagi pendidik PAUD untuk terus mengembangkan kegiatan bermain meremas dengan menggunakan media lain.

\section{Daftar Pustaka}

Alfiana, T., \& Lestariningrum, A. (2015). Penerapan Metode Proyek Untuk Meningkatkan Keterampilan Sosial Anak Dalam Bekerjasama Pada Anak Didik Kelompok B2 Di TK Kreatif Zaid Bin Tsabit kecamatan Nglegok Kabupaten Blitar. Jurnal Pinus, 1(3): 199206

Andini, P. P., \& Lestariningrum, A. (2018). Bermain Dan Permainan Anak Usia Dini: Sebuah Kajian Teori dan Praktik. Nganjuk: Penerbit Adjie Media Nusantara.

Beaty, J. J. (2013). Observasi Perkembangan Anak Usia Dini. Jakarta: Kencana Prenada Media Group

Claudia, E. S., Widiastuti, A. A., \& Kurniawan, M, (2018). Origami Game For Improving Fine Motor Skills for children 4-5 Years Old In Gang Buaya Village in Salatiga. Jurnal Obsesi: Jurnal Pendidikan Anak Usia Dini, 2(2): 143-148.

Fulanatin, F., \& Simatupang, N. D. (2016). Peningkatan Kemampuan Motorik Halus Melalui Kegiatan Meremas kertas pada Anak Usia 3-4 Tahun. Jurnal PAUD Teratai, 5(1): 1-5

Hurlock, E. (1978). Perkembangan Anak. Jakarta: PT Aksara Pratama

Jannah, A. R., \& Lestariningrum, A. (2018). Peningkatan Kemamapuan Motorik Kasar Anak Usia 5-6 Tahun Melalui Permainan Injak Ekor. Journal of Early Childhood care \& Education, 1(1): 1-6 
Lestariningrum, A. (2019). Pengaruh Senam bebek Berenang Terhadap kemampuan Motorik Kasar Anak Usia 3-4 Tahun. Jurnal Efektor, 6(1): 1-6.

Moyses, K. (2016). Building fine motor skills and why it matters. Artikel Online Michigan state University:https://www.canr.msu.edu/news/building_fine_motor_skills_and_why_it_matt ers. Diakses Maret 2020

Miles, M. B.., \& Huberman, A. M. (1992). Analisis Data Kualitatif : Buku Sumber Tentang Metode-metode Baru. Jakarta: Universitas Indonesia.

Najamuddin, N. (2017). Peningkatan Keterampilan Motorik Halus Melalui Bermain Bubur Kertas Di kelompok B TK Al Ilham NW Selusuh. Jurnal Golden Age universitas Hamzanwadi, 1(2): 103-111

Sartika, Y. (2013). Meningkatkan Kemampuan Motorik Halus Melalui meremas Adonan Pada Anak Tunagrahita Ringan. E-JUPEKhu: Jurnal Ilmiah Pendidikan Khusus, 1(1): 266-279

Santrock, J. W. (2002). Life-span Development Perkembangan Masa Hidup Edisi Kelima. Jakarta: Penerbit Erlangga

Widayati, S., Adhe, K. R., Nafisa, F., \& Silvia E. F. (2019). Tahapan Menggunting dalam Meningkatkan Kemampuan Motorik Halus Anak Usia Dini. Child Education Journal, 1(2): $50-57$

Yunia, H., Sumarsih., \& Wembrayarli. (2017). Meningkatkan keterampilan Motorik Halus Anak Melalui Kegiatan Membentuk Dengan Menggunakan Media Spons Di PAUD Assalam Kota Bengkulu. Jurnal Ilmiah Potensia, 2(2): 107-116. 